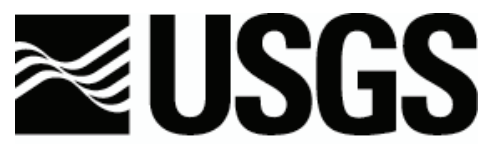

science for a changing world

\title{
Aqueous geochemical data from the analysis of stream water samples collected in August 2004 - Taylor Mountains 1:250,000 scale Quadrangle, Alaska
}

By Bronwen Wang, Seth Mueller, Elizabeth Bailey, Greg Lee.

Any use of trade, firm, or product names is for descriptive purposes only and does not imply endorsement by the U.S. Government

Open-File Report 2006-1175 


\section{U.S. Department of the Interior}

\section{U.S. Geological Survey}

U.S. Geological Survey, Reston, Virginia 2006

For product and ordering information:

World Wide Web: http://www.usgs.gov/pubprod

Telephone: 1-888-ASK-USGS

For more information on the USGS - the Federal source for science about the Earth, its natural and living resources, natural hazards, and the environment:

World Wide Web: http://www.usgs.gov

Telephone: 1-888-ASK-USGS

Although this report is in the public domain, permission must be secured from the individual copyright owners to reproduce any copyrighted material contained within this report. 


\section{Contents}

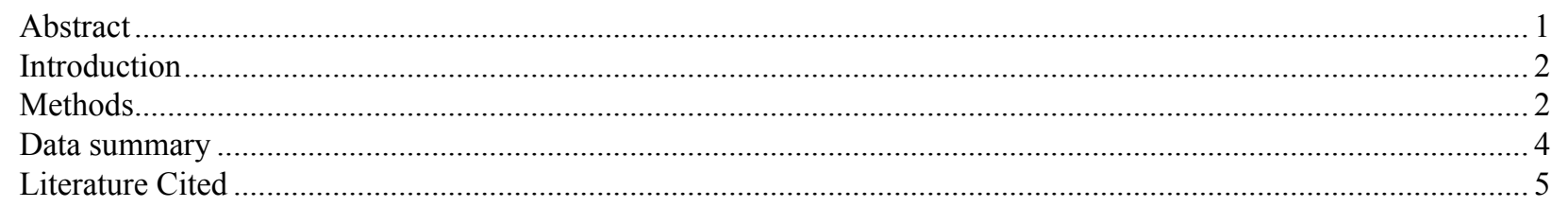

\section{Figures}

1. Location of the 2004 stream water sites in the Taylor Mountains C1, C2, D1, D2, and D4 1:63,360 scale

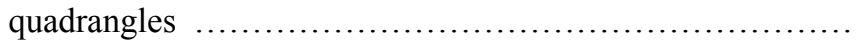

2. Tri-linear diagram showing the major ions ratios in stream water samples collected from the Talyor Mountains C1, C2, D1, D2, and D4 quadrangle

\section{Tables}

1. Summary statistics for stream water samples from the Taylor Mountains quadrangle for 2004 ......

2a. Concentrations of major and trace elements in duplicate and blank samples from the Taylor Mountains quadrangle, 2004.

2b. Concentrations DOC, methyl-Hg, and total-HG induplicate and blank samples from the Taylor

Mountains quadrangle, 2004 .

\section{Appendix}

A. Analytic data for stream water samples collected in 2004 from the Taylor Mountain quadrangle

B. Standard reference material data accompanying stream water samples collected in 2004 from the Taylor

Mountain quadrangle

\section{Conversion Factions and Abbreviated units}

$\begin{array}{ccc}\text { Multiply } & \text { by } & \text { To obtain } \\ \text { meter }(\mathrm{m}) & 3.281 & \text { foot } \\ \text { kilometer }(\mathrm{km}) & 0.6214 & \text { mile } \\ \text { square kilometer }(\mathrm{km}) & 0.3861 & \text { square mile }\end{array}$

In this report, temperature is reported in degrees Celsius $\left({ }^{\circ} \mathrm{C}\right)$, which can be converted to degrees Fahrenheit $\left({ }^{\circ} \mathrm{F}\right)$ by the following equation:

$$
\left({ }^{\circ} \mathrm{F}\right)=1.8\left({ }^{\circ} \mathrm{C}\right)+32
$$

\section{Other Abbreviated Units}


L, liter

$\mathrm{mg} / \mathrm{L}$, milligram per liter

$\mu \mathrm{g} / \mathrm{L}$, microgram per liter

$\mathrm{ng} / \mathrm{L}$, nanogram per liter

$\mu \mathrm{m}$, micrometer

$\mu \mathrm{g} / \mathrm{g}$, microgram per gram

ng/g, nanogram per gram

$\mathrm{mg} / \mathrm{kg}$, milligram per kilogram

$\mu \mathrm{S}$, microsiemens 


\section{Aqueous geochemical data from the analysis of stream water samples collected in August 2004 - Taylor Mountains 1:250,000 scale Quadrangle, Alaska}

By Bronwen Wang, Seth Mueller, Elizabeth Bailey, Greg Lee.

\section{Abstract}

We report on the chemical analysis of water samples collected from the Taylor Mountains 1:250,000 quadrangle. Samples were collected as part of the multi-year U.S. Geological Survey's project -- Geologic and Mineral Deposit Data for Alaskan Economic Development. Data presented here are from water samples collected primarily in the northeastern part of the Taylor Mountains quadrangle. The data include samples taken from the Taylor Mountains C1, C2, D1, D2, and D4 1:63,360 scale quadrangles. The data are being released at this time with minimal interpretation. Site selection was based on a regional sampling strategy that focused on first and second order drainages. Water sampling site selection was based on landscape parameters that included physiography, wetland extent, lithological changes, and the cursory field review of the mineralogy from the pan concentrates. Stream water in the Taylor Mountians quadrangle is dominated by bicarbonate $\left(\mathrm{HCO}_{3}{ }^{-}\right)$, though in a few samples more than $50 \%$ of the anionic charge can be attibuted to sulfate $\left(\mathrm{SO}_{4}{ }^{2-}\right)$. The major-cation chemistry range from $\mathrm{Ca} / \mathrm{Mg}$ dominated to a mix of $\mathrm{Ca} / \mathrm{Mg} / \mathrm{Na}+\mathrm{K}$. Good agreement was found between the major cation and anions in the duplicate samples. Many trace elements were at or near the method detection limit in these samples but good agreement was found between duplicate samples for elements with detectable concentrations. Major ion concentrations were below detection in all field blanks and the trace elements concentrations generally were below detection. However, Ta (range $0.9-.1 \mathrm{ug} / \mathrm{L})$ and $\mathrm{Zn}(1$ to $3.5 \mathrm{ug} / \mathrm{L})$ were detected in all blanks and Ba ( $0.24 \mathrm{ug} / \mathrm{L})$ and Th $(0.2 \mathrm{ug} / \mathrm{L})$ were detected in one blank. There was good agreement between dupilicate total- and methylmercury and DOC samples; however, total mercury, methyl-mercury and dissolve organic carbon (DOC) were detected in the blank at $2.35 \mathrm{ng} / \mathrm{L}, 0.07 \mathrm{ng} / \mathrm{L}$ and $0.57 \mathrm{mg} / \mathrm{L}$, respectively. 


\section{Introduction}

Geologic, geochemical, and geophysical data have been important in the economic development of Alaska, but, even at a reconnaissance scale of 1:250,000, less than half of Alaska has adequate data to assess the undiscovered mineral resource potential. Government agencies and private industry have requested the collection of new geological data and in response the U.S. Geological Survey initiated the "Geologic and Mineral Deposit Data for Alaskan Economic Development" project with the goal of obtaining geological data for data poor regions of the state.

Southwestern Alaska, which includes the Taylor Mountains quadrangle, is a region with only minimal geological data available. However, based on the limited data and known mineral prospects, the region is thought to have a high potential for undiscovered mineral resources. Therefore, the Geologic and Mineral Deposit Data for Alaskan Economic Development project has initially focused collection of new geologic, geochemical, and geophysical data in this area. The data presented here are the analytic chemical data for stream water samples collected primarily in the northeastern part of the Taylor Mountains quadrangle. The samples were collected in August 2004 from the Taylor Mountains C1, C2, D1, D2, and D4 quadrangles (fig.1) and are being released at this time with minimal interpretation.

\section{Methods}

The water sampling sites represent a subset of sites used for sediment sampling for the overall project goal. Site selection was based on a regional sampling stragety that focused on first and second order drainages. Water sampling site selection was based on landscape parameters that included physiography, wetland extent, lithological changes, and the cursory field review of the mineralogy from the pan concentrates. These are the initial samples of a multi-year effort intended to cover the variety of landscape and minerlization conditions found within the Taylor Mountains Quadrangle.

Dip-composite water samples were collected using telfon collection bottles. The collection bottles were cleaned in a boiling nirtic-acid bath prior to field deployment (Olson and DeWild, 1999). In the field the sample bottles were carried capped in a clean plastic-resealable bag in the samplers' backpack. The sample collection bottle was rinsed with copious amounts of native water pior to sample collection. Sampling consisted of dipping the 
sample bottle at several locations across the stream upstream of all other sampling activities. Samplers wore disposable gloves during the sampling and sample processing. Waters for major- and trace-element analysis were filtered immediately after collection through a $0.45 \mu \mathrm{m}$ syringe-end filter fitted to a $60 \mathrm{ml}$ syringe into high density polyethylene bottles. Samples for major cation $(\mathrm{Ca}, \mathrm{Mg}, \mathrm{K}, \mathrm{Na})$ and trace-element analysis were preserved with ultra-high-purity $\mathrm{HNO}_{3}$. Samples for alkalinity and major anion $\left(\mathrm{SO}_{4}, \mathrm{Cl}, \mathrm{F}, \mathrm{NO}_{3}\right)$ analysis were filtered but not acidified. A single samples were taken for both low-level total and methyl-mercury analysis, and a final sample was collected for dissolved organic carbon (DOC) analysis. The mercury and DOC samples were collected as above. However, the total- and methyl- mercury sample was not filtered and was simply transferred from the collection bottle to a boiling nitric-acid cleaned teflon sample bottle. The mercury sample was preseved with $5 \%$ mercury-free hydrochloric acid. Samples for DOC were filtered through a $0.45 \mu \mathrm{m}$ baked glass-fiber fliter into a glass vial. Both the mercury and DOC samples were refrigerated and they were shipped, on ice, to the laboratory for analysis.

Samples for major and trace element analysis were shipped to the Denver laboratories of the USGS for analysis. Major cations ( $\mathrm{Ca}, \mathrm{Mg}, \mathrm{K}, \mathrm{Na}$ ) and trace element concentrations were determined by inductively-coupled plasma mass spectrometry (ICP-MS) and major anions ( $\left.\mathrm{F}, \mathrm{Cl}, \mathrm{NO}_{3}, \mathrm{SO}_{4}\right)$ by ion chromatography (IC) (Lamothe and others, 2002; Theodorakos and others, 2002). Alkalinity was determined using a preset endpoint (pH 4.5) autotitration system (Theodorakos, 2002). Laboratory procedures require instrument calibration with an appropriate calibration standard for elements to be reported and analysis of standard reference materials for those elements with appropriate standard reference material. In general the instrument calibration and quality control procedures for the laboratory are: 1) daily hardware and software checks to insure the instrument and its components are working properly. 2) calibration of the instrument using appropriate standards. The calibration standards used contain all the elements that are reported from the analysis. 3) Standard reference materials run where appropriate. For water samples the standard reference materials are aqueous reference materials from the U.S. Geological Survey Water Resource Division. Information regarding these reference materials is at http://bqs.usgs.gov/SRS/. 4) Samples are run. Every tenth sample is a calibration check solution (i.e. a calibration standard run as a sample) and after every 20 samples the machine is recalibrated and standard reference materials are run. 5) Each run concludes with a standard reference material (Lamothe, personal communication).

Mercury and DOC samples were sent to the USGS mercury lab in Middleton, WI. Mercury concentrations were determined using cold vapor atomic fluorescence spectrometry (DeWild and others, 2002; Olson and DeWild, 1999) and DOC was determined by heat assisted persulfate oxidation with detection by nondispersive infrared 
detection (Olson, and De Wild, 1997). Laboratory procedures for ensuring total and methyl-mercury, and DOC data quality are given in Olson and DeWild (1999) and Olson and DeWild (1997), respectively.

The analytic data is stored in the USGS National Geochemical Database and the Wisconsin mercury lab data base.

\section{Data Summary}

Major and trace element data are summarized in tables 1 and 2, and the analytic data is presented in the appendices. Elements determined by ICP-MS and IC are censored to the lower limit of determination (LLD) for the method as determined in Lamothe and others (2002), and Theodorakos and others (2002). The method LLD is taken as 5 times the standard deviation of the instrument response on a blank solution. All values below the LLD are reported as less than the LLD. In some instances the LLD has changed since the methods were publish and the LLD values used in this data release are given in table 1. Due to instrumental variations and matrix interferences analytic data may be censored higher than the typical LLD by the analyst. Method performance and method detection limits for the mercury and methyl-mercury are given in Olson and DeWild (1999) and DeWild and others (2002) and Theodorakos, P.M. (2002) details the uncertainty assignment information for the alkalinity determination method.

The major anion chemistry of the samples collected in 2004 from the Taylor Mountains quadrangle is dominated by bicarbonate $\left(\mathrm{HCO}_{3}{ }^{-}\right.$, calculated from the alkalinity) though in a few samples more than $50 \%$ of the anionic charge can be attributed to sulfate $\left(\mathrm{SO}_{4}{ }^{2-}\right)$. The major cation chemistry ranges from $\mathrm{Ca} / \mathrm{Mg}$ dominated to a mix of $\mathrm{Ca} / \mathrm{Mg} / \mathrm{Na}+\mathrm{K}$ (fig. 2). Of the trace elements analyzed, $\mathrm{Be}, \mathrm{Cd}, \mathrm{Cr}, \mathrm{Ga}$, and $\mathrm{Ge}$ were not detected in water samples. Minimum and maximum concentrations, mean, and median values of the elements in water are given in Table 1 and the analytic data is given in appendix A. Summary statistics were not calculated if the number of qualified values exceeded $25 \%$ of the sample (table 1 ). For elements with qualified values summary statistics were calculated using the Kaplan-Meier method for cencored data as detailed in Helsel (2005).

Duplicate samples were taken for trace element and major ion analyisis at sites 04TA006, 04TA018, 04TA031, 04TA111, 04TA125 and 04TA132 (table 2a). Dupilcate samples were taken for total- mercury and methyl-mercury, and DOC analysis at sites 04TA026, 04TA037, 04TA111 (table 2b). Good agreement was found between the major cation in the duplicate samples ( $\mathrm{Ca} 0-1.7 \%$ difference, $\mathrm{Mg} 0-1.4 \%$, Na $0-1.5 \%$, K no difference) (table 2a). Generally good agreement was found between the major anions: however, an 18\% difference 
in alkalinity concentrations was found between duplicates of $04 \mathrm{TA} 006$ and a $65 \%$ difference in choride concentrations was found between duplicates of 04TA125 (table 2a). Many trace elements were at or near the method detection limit in these samples and good agreement was found between duplicate samples for elements with detectable concentrations (Table2). Major ion concentrations were below detection in all field blanks and generally the trace elements concentration were below detection. However, Ta (range $0.9-0.1 \mathrm{ug} / \mathrm{L}$ ) and $\mathrm{Zn}(1$ to $3.5 \mathrm{ug} / \mathrm{L})$ were detected in all blanks and $\mathrm{Ba}(0.24 \mathrm{ug} / \mathrm{L})$ and $\mathrm{Th}(0.2 \mathrm{ug} / \mathrm{L})$ were detected in one blank (Table 2a).

There was good agreement between dupilicate total- and methyl- mercury and DOC samples; however, total mercury, methyl-mercury and DOC were detected in the blank at $2.35 \mathrm{ng} / \mathrm{L}, 0.07 \mathrm{ng} / \mathrm{L}$ and $0.57 \mathrm{mg} / \mathrm{L}$ respectively (Table 2b).

\section{Literature Cited}

DeWild, J.F., Olson, M.L., and Olund, S.D., 2002, Determination of Methyl Mercury by Aqueous Phase Ethylation, Followed by Gas Chromatographic Separation with Cold Vapor Atomic Fluorescence Detection: Open-File Report 01-445. http://infotrek.er.usgs.gov/mercury/methods.html

Lamothe, P.J., Meier, A.L., Wilson, S.A., 2002, The determination of fourty-four elements in aqueous samples by inductively coupled plasma-mass specrtometry: In Taggart, J. E. editor, Analytical methods for chemical analysis of geologic and other material, U.S. Geological Survey: Open-file report 02-223,

http://pubs.usgs.gov/of/2002/ofr-02-0223/.

Helsel, D. R., 2005, Nondetects and Data Analysis-Statistics for censored environmental data: Wiley-Interscience, Hoboken, New Jersey, $250 \mathrm{pp}$.

Olson, M.L., and DeWild, J.F., 1997, Standard operating procedure for the determination of dissolved organic carbon in water: WDML SOP006, 9 pp., http://infotrek.er.usgs.gov/mercury/sop_6_port.htm\#0.0

Olson, M.L., and DeWild, J.F., 1999, Low-Level Collection Techniques and Species-Specific Analytical Methods for Mercury in Water, Sediment, and Biota: U. S. Geological Survey Water Resources Investigations 99-4018-B, $11 \mathrm{p}$.

Theodorakos, P.M., 2002, determination of Total alkalinity using a preset endpoint (pH4.5) Autotitration System: In Taggart, J. E. editor, Analytical methods for chemical analysis of geologic and other material, U.S. Geological Survey: Open-file report 02-223, http://pubs.usgs.gov/of/2002/ofr-02-0223/.

Theodorakos, P.M., d'Angelo, W.M., Ficklin, W.H., 2002, Floride, chloride,nitrate, and sulfate in aqueous solutions utilizing AutoSuppression chemically suppressed ion chromatography: In Taggart, J. E. editor, Analytical methods for chemical analysis of geologic and other material, U.S. Geological Survey: Open-file report 02223, http://pubs.usgs.gov/of/2002/ofr-02-0223/. 
Figure 1. Location of the 2004 stream water sites in the Taylor Mountains C1, C2, D1, D2, and D4 $1: 63,360$ scale quadrangles. Site number is located to the right or above the point unless designated with an arrow.

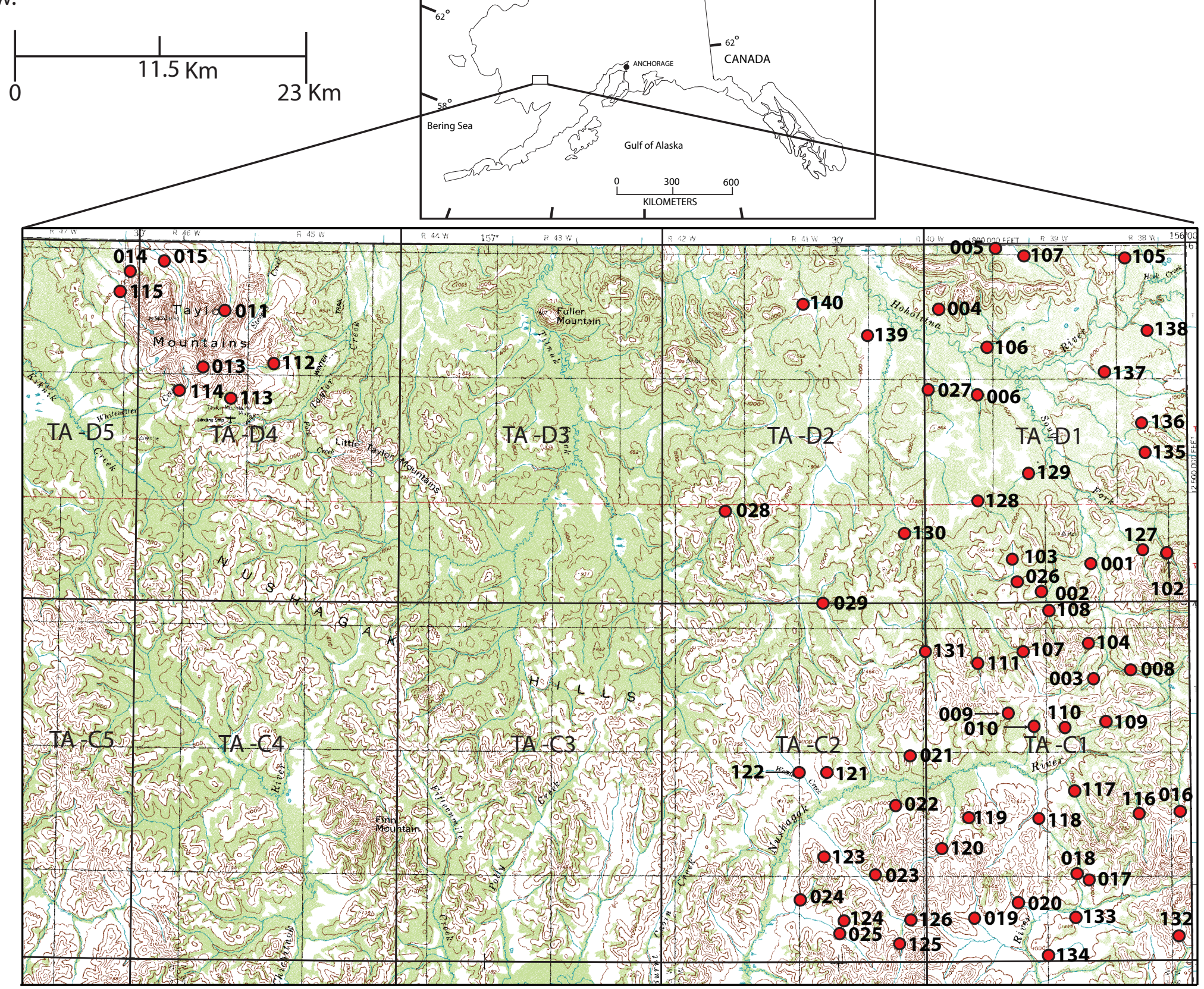




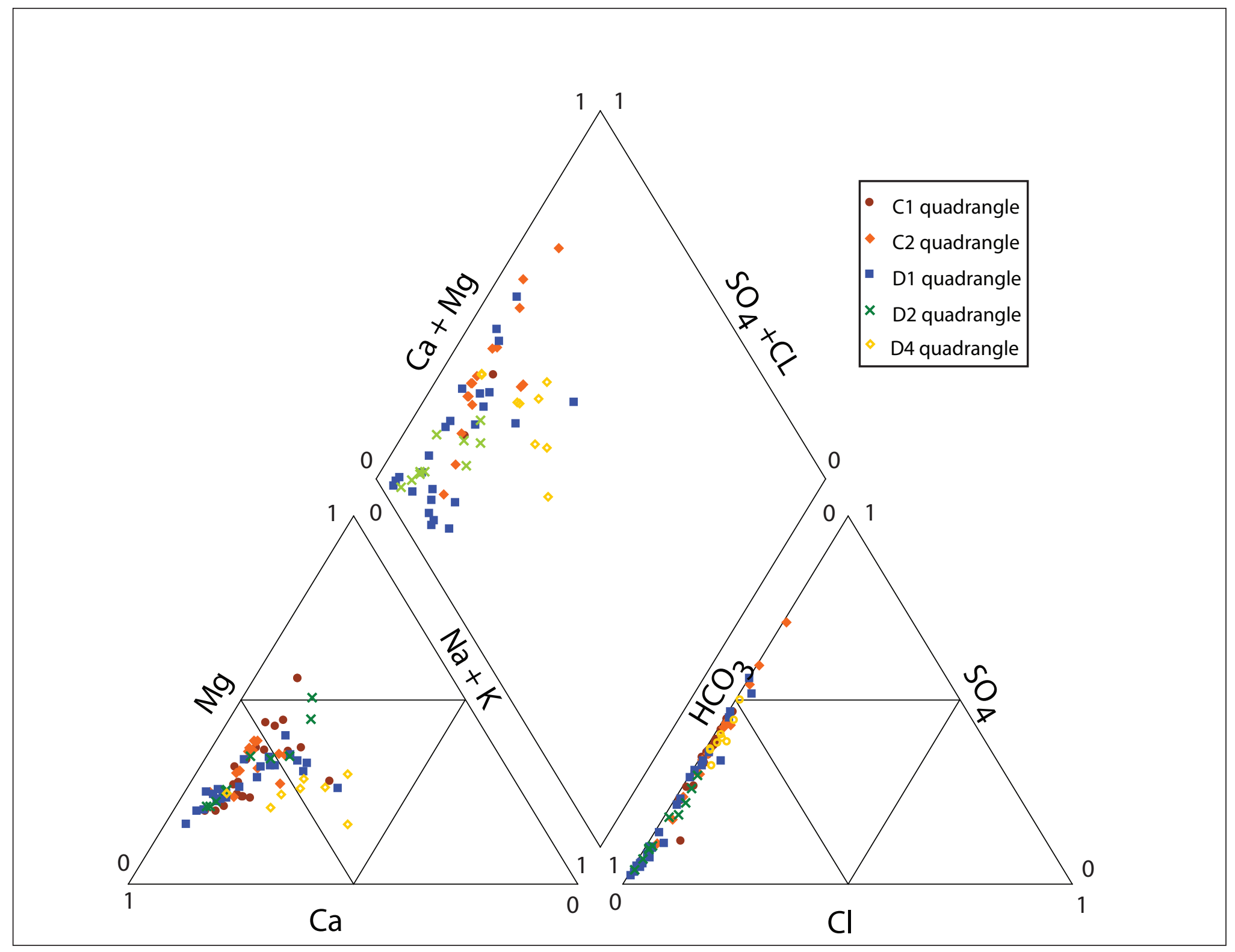

Figure 2.Tri-linear diagram showing the major ions ratios in stream water samples collected from the Talyor Mountains $\mathrm{C} 1, \mathrm{C} 2, \mathrm{D} 1, \mathrm{D} 2$, and $\mathrm{D} 4$ quadrangles . 